\title{
AKAR TEOLOGIS KETIMPANGAN GENDER: Pemilxiran Feminisme Riffat Hassan
}

\author{
Oleh : Maftukhatusolikhah
}

\section{Abstract}

The consciousness of gender discrimination which causes discrimination treatment toward man and women, emerges feminism movement around the world, including the Islamic World. It can be proven by emergence of some Muslims who involve in feminism movement in Muslim countries. One of them is Riffat Hassan, theologian-feminist who is born in Lahore, Pakistan. Feministic thought of Riffat Hassan is a formulation from complex situation, which is influenced by elements of culture, society, politic, and her education. The interesting thing of Riffat Hassan's thought is her effort to search theological doctrine (Qur'an and Hadits). According to Riffat, some Muslim interpreters. who are men intentionally misinterpret it. Therefore, Riffat devotes her ability to reinterpret the theological doctrines. Even, she tries to criticize authenticity and authority of Hadith, which is used by the classical interpreters as basic of their opinion. This study will discus and criticize thought of Riffat Hassan who tries to explain eternal prophetic message of Qur'an, especially verses pertaining to women in the context of time and space, it will produce new reading of Qur'an, in feminism perspective.

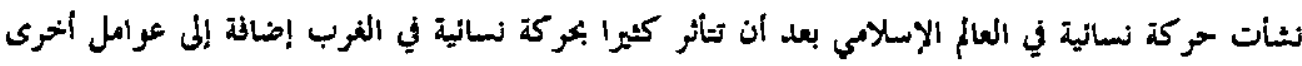

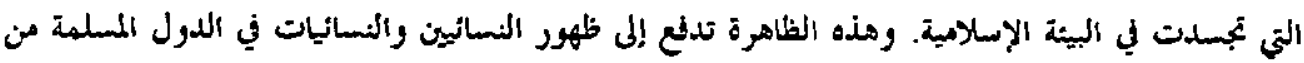

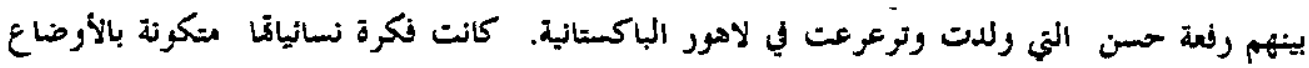

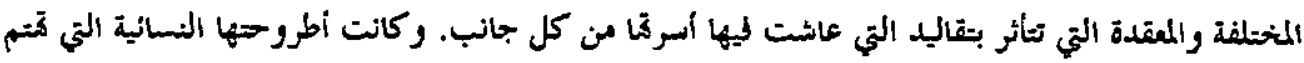

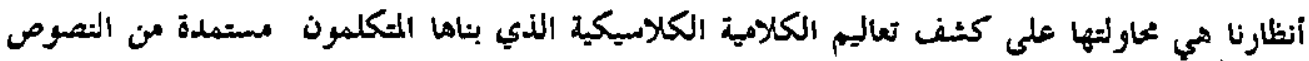

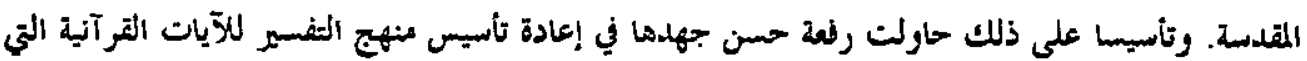

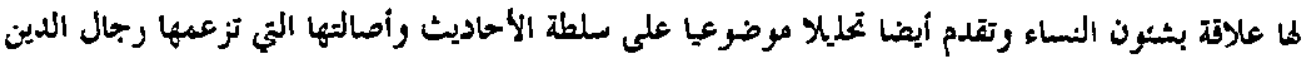

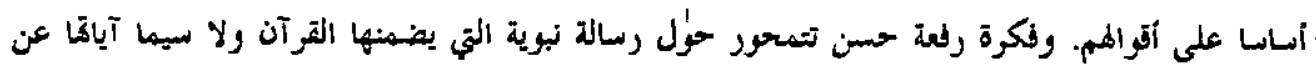

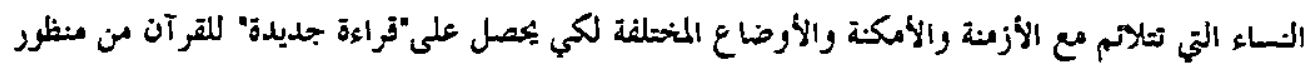

Kata Kunci: Feminisme, Gender, Teologis

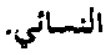

- Mahasiswa Program Studi Hukum Islam, Konsentrasi Muamalat, Program Pasca Sarjana IAIN Sunan Kalijaga Yogyakarta. 


\section{A. Pendahuluan}

$\mathrm{D}$ alam masyarakat yang menganut sistem patriarchy ${ }^{\prime}$, posisi' perempuan kurang diuntungkan karena merupakan sub-ordinat di bawah laki-laki. Konsekuensinya perempuan harus tunduk kepada laki-laki karena keđudukannya yang dianggap lebih rendah itu. Terlebih lagi anggapan tersebut seolah-olah mendapat legitimasi dari doktrin-doktrin teologis, termasuk alQur'an dan al-Hadis yang merupakan sumber utama ajaran Islam.

Di tengah konteks masyarakat yang memposisikan perempuan begitu rendah, "pesan profetik abadi" yang dibawa al-Qur'an dan Sunnah Nabi itu sesungguhnya merupakan terobosan yang "radikal" dan "revolusioner". Namun yang menjadi persoalan, pesan-pesan universal yang dibawa al-Qur'an tersebut, harus dijabarkan dalam konteks ruang dan waktu, dan dalam dimensi sosio-historis yang kongkrit. Ketika "memasuki' dimensi kesejarahan, yaitu konteks zaman dan struktur masyarakat yang nyata, muncul persoalan kunci, yang nantinya mendorong usaha-usaha untuk "membaca" (menafsirkan) kembali kitab suci dengan optik yang berbeda. ${ }^{2}$

Keadaan tersebut antara lain disebabkan oleh tidak-adanya metile penafsiran al-Qur'an yang sepenuhnya obyektif. Karena berbagai rincian penafsiran, kadangkala mencerminkan pilihan subyektif para penafsirnya, tanpa mementingkan maksud dari ayat yang hendak ditafsirkan. ${ }^{3}$ Tafsir-tafsir tradisional, ${ }^{4}$ yang ditulis secara eksklusif oleh kaum laki-laki, dalam hal menafsirkan ayat-ayat yang berkenaan dengan perempuan, berarti laki-laki dan pengalaman laki-lakilah yang dimasukkan dalam penafsiran itu. Sementara itu, perempuan dan pengalamannya ditiadakan. Atau visi, perspektif, keinginan, serta kebutuhan kaum perempuan ditafsirkan menurut pandangan kaum pria. Tidak terdengarnya suara kaum perempuan selama periode kritis perkembangan penafsiran al-Qur'an, secara keliru disamakan dengan ketidakberadaan suara (kedudukan) kaum perempuan dalam pandangan al-Qur'an itu sendiri. ${ }^{5}$

1 Patriarchy adalah suatu susunan masyarakat dengan ayah/laki-laki sebagai kepala keluarga, suku atau masyarakat. Masyarakat Ișlam pada umumnya menganut sistem patriarkhi.

2 Trisno S. Sutanto, 1999, "Tulang Rusuk Adam, Membaca Kembali Kitab Suci dengan Optik Perempuan" dalam Tashwirul Afkar, Jakarta, Lakspedam NU, No. 5. hal. 3.

"Amina Wadud Muhsin, 2001, "Al-Qur"an dan Perempuan", dalam Charles Kurzman (ed), Wacana Islam Liberal, Pemikiran Islam Kontemporer tentang Isu-isu Global, alih bahasa oleh Bahrul Ulum, Jakarta: Paramadina, hal. 186.

4 Tafsir tradisional -baik yang berasal dari era klasik maupun modern-, memberikan interpretasi keseluruhan isi al-Qur‘an, yang metodologi pembahasannya dimulai dengan ayat pertama pada surat pertama, kemudian ayat kedua pada surat tersebut, seterusnya hingga ayat terakhir pada surat terakhir al-Qur'an. Para Mufassirnya hampir tidak melakukan upaya untuk mengenali lebih jauh tema-temanya, atau membahas hubungar antara ayat-ayat alQur'an secara tuntas. Amina Wadud Muhsin, op. cit., hal. 186.

slbid., hal. 187.

- Feminisme adalah suau kesadaran akan penindasan dan pemerasan terhadap perempuan dalam masyarakat di 
Oleh karena itu, ketika feminisme ${ }^{6}$ yang merupakan reaksi dari ketimpangan dan ketidakadilan yang menimpa kaum perempuan, memasuki dunia Islam, bermunculan feminis-feminis Muslimah, yang atas dasar keyakinan keislaman mereka, berusaha mengkritisi penafsiran-penafsiran ulama-ulama tradisional yang sarat dengan gender bias. Mereka juga melakukan reinterpretasi terhadap ayat-ayat al-Qur 'an tersebut, bahkan dengan mempertanyakan kembali otoritas dan otentisitas hadis-hadis yang dijadikan sandaran oleh para penafsir terdahulu.

Tulisan ini secara khusus akan mencermati pemikiran-pemikiran Riffat Hassan salah seorang feminis Muslimah tentang feminisme, dengan menelusuri doktrin-doktrin teologis (al-Qur'an maupun al-Hadis). Untuk dapat melihat secara kritis dan tajam terhadap gagasan dan pemikiran Riffat Hassan ini, terlebih dahulu akan diuraikan latar belakang historisnya, kemudian landasan teori dan konstruksi metodologi yang ditawarkannya, konsekwensi logis pemikirannya, analisa krirtis terhadap pemikiran-pemikirannya, dan diakhiri dengan suatu kesimpulan.

\section{B. Latar Belakang Historis dan Karir Intelektual Riffat Hassan}

Riffat Hassan adalah seorang feminis muslimah kelahiran Lahore-Pakistan, ${ }^{7}$ dari keluarga sayyid ${ }^{8}$ kelas atas yang paling terkemuka di kota itu. Ia menghabiskan 17 tahun pertamanya di tanah kelahirannya dengan jaminan hidup yang terbaik dan bersekolah menengah berbahasa Inggris paling bonafide. Namun, Riffat mengaku tidak merasa tinggal dalam sebuah 'rumah', jika seseorang mendefinisikannya sebagai tempat dimana terdapat cinta, kehangatan dan rasa aman. Hal ini disebabkan adanya konflik berkepanjangan, karena perbedaan prinsip dan karakter yang'sangat mendasar antara kedua orang tuanya.

Ayahnya, Begum Shahiba, begitu orang-orang memanggilnya, merupakan seorang patriakh daerah itu, yang sangat disukai dan dihormati oleh semua orang, dan mempunyai kepedulian sosial yang tinggi. Ia juga seorang tradisionalis (Riffat sangat membenci ke-tradisionalannya ini), yang berpandangan bahwa yang terbaik bagi seorang gadis adalah menikah pada

tempat kerja, keluarga, dan masyarakat, disertai tindakan sadar dari perempuan atau lelaki untuk mengubah keadaan tersebut. Lihat Kamla Bashin dan Nighat Said Khan, 1995, Persoalan Pokok Mengenai Feminisme dan Relevansinya, alih bahasa oleh S. Herlina, Gramedia Pustaka Utama, Jakarta, hal.5. Adapun semangat yang mendasart gerakan feminisme adalah semangat keadilan; persamaan, dan kebebasan perempuan yang selama ini terhimpit persoalan gender. Lihat Abdul Mustaqim, 1999, "Feminisme Dalam Pemikiran Riffat Hassan', dalam $a l$-Jami' $a h$, Yogyakarta: IAIN Sunan Kalijaga, No. 63/,VI, hal. 108.

7 Tidak ada data akurat tentang tanggal dan tahun kelahirannya, tapi jika menghitung tahun-tahun yang dilalui semasa hidupnya baik ketika masih di Pakistan atau setelah hijrah ke luar negeri, baik Inggris maupun Amerika, Riffat diperkirakan lahir sekitar tahun 1945.

"Sayyid adalah keturunan Nabi Muhammad, dianggap sebagai kasta umat Islam yang paling tinggi, walaupun umat Islam memprotes bahwa Islam tidak mempunyai sistem kasta. Lihat Fatima Mernissi dan Riffat Hasan, 2000, Setara di Hadapan Allah, alih bahasa oleh tim LSPPA, cet III Yogyakarta: LSPPA, hal. 6. 
usia 16 tahun dengan laki-laki pilihan orang tua mereka. Sedangkan ibunya mempunyai sikap untuk tidak mau kompromi dengan kebudayaan Islam tradisional, yang sebagian besar dilakukannya dengan menolak kuitur yang meneguhkan inferioritas dan ketundukan perempuan kepada laki-laki. Ibunya tidak tunduk pada ayahnya. Ibunya lebih memperhatikan anak-anak perempuannya daripada anak laki-lakinya, dan percaya bahwa mendidik anak perempuan lebih penting, karena perempuan dilahirkan dalam masyarakat Muslim dengan rintangan yang sangat hebat. Riffat Hassan mengkategorikan ibunya sebagai seoarang feminis radikal, karena penolakannya terhadap citacita dan praktek budaya patriarkhi, serta komitmennya yang penuh gairah kepada pembebasan anak-anak perempuannya dari "charderwari" (empat dinding) rumah tangga yang merupakan male domination. Dalam masyarakatnya, ibunya dipandang sebagai pemberontak yang membahayakan. ${ }^{9}$

Walaupun ibunya telah berusaha menjadi figur penyelamat yang melindungi anak-anak perempuannya agar tidak menjadi korban di altar konvensionalisme buta, ternyata tidak berhasil menyelamatkan kedua kakak perempuan Riffat dari pernikahan muda (usia 16 tahun). Oleh karena itu, ketika menginjak usia sebelas tahun, perjuangannya sebagai 'aktivis feminis' bermula, yaitu dengan menuangkan pikiran-pikirannya lewat karya-karya puisi dan soneta yang berisi . kritik terhadap kondisi sosio-kultural masyarakat patriarkhal saat itu. ${ }^{10}$

- Tatkala berusia 12 tahun, ia mulai berperang secara terbuka melawan pendirian konvensionalisme ayahnya yang kaku, dengan menolak keluar dari sekolah campuran untuk pindah pada sekolah khusus perempuan. Kemandirian pikiran dan tindakannya, ternyata mengancam gagasan ayahnya tentang "kehormatan" keluarga. Pada saat yang sama Riffat meningkatkan kehormatan keluarganya dengan menjadi nomor satu dari 24000 mahasiswa pada ujian lanjutan. ${ }^{31}$

Pada usia 17 tahun, Riffat pergi ke Inggris untuk melanjutkan pendidikan tingginya di St. Mary's College University of Durham. Setelah tiga tahun studi, Riffat berhasil lulus dengan predikat cumlaude di bidang sastra Inggris dan filsafat. Pada usia 24 tahun, ia berhasil meraih gelar doktor di bidang filsafat dengan disertasinya tentang filsafat Muhamad Iqbal, seorang penyair dan filosof Pakistan. ${ }^{12}$

Setelah tujuh tahun di Inggris Riffat kembali ke Pakistan dan bekerja sebagai wakil direktur pada "sel otak" Departemen Penerangan Federal. Ia menjalani pernikahan dua kali, dan dikaruniai seorang putri dari suami pertama. Namun kedua pernikahannya mengalami kegagalan. Kemudian ia hijrah ke Amerika Serikat, dan merintis karir intelektualnya di sana.

\footnotetext{
9 Fatima Mernissi dan Riffat Hassan, ibid., hal. 6-9.

10 Ibid., hal. 15.

"Ibid., hal. 24.

"Ibid., hal.18.
} 
Keseriusannya dalam mempelajari dan mereinterpretasi teks-teks al-Qur'an terutama ayat-ayat yang berkenaaan dengan perempuan, bermula sejak tahun 1974 ketika ia menjadi dosen penasihat organisasi mahasiswa Islam cabang Oklahoma State University of Stillwater, saat ia diminta untuk memberikan ceramah tentang isu-isu keperempuanạn. ${ }^{13}$ Kajian yang semula bersifat tuntutan akademis, berubah menjadi kesadaran moral dalam suatu pencarian kebenaran dan keadilan atas nama perempuan Muslim yang mengalami "perbudakan tak terucapkan' yang dibebankan pada mereka atas nama agama dan Tuhan. Oleh karena itu, sebagai a true believer, Riffat merasa perlu untuk melakukan kajian-kajian terhadap al-Qur'an yang diyakininya sebagai sabda Tuhan yang merupakan norma ideal Islam sepanjang zaman.

Kemudian sejak tahun 1976, Riffat menjadi profesor dan mengajar pada jurusan Religious Studies di Universitas Louisville-Kentucky, dan menjadi ketua program di sana sekitar tahun 1987-1988. Dalam karir intelektual selanjutnya, Riffat juga menjadi dosen tamu di Divinity School Harvard University. ${ }^{14}$

Pada tahun 1983-1984, Riffat datang ke Pakistan untuk melakukan penelitian ketika masa pemerintahan Zia ul-Haq gencar melakukan "islamisasi". Riffat menyaksikan dengan kegelisahan yang memuncak pemberlakuan undangundang anti perempuan yang diatasnamakan Islam. Dalam hal ini; di balik kedok "islamisasi" ia meyakini agama telah dijadikan lebih sebagai alat penindasan daripada sebagai sarana pembebasan. ${ }^{15}$

Karya-karya ilmiah Riffat Hassan mengenai isu-isu perempuan ini, antara lain Equal Before Allah, yang merupakan masterpiecenya. Karya lainnya adalah Women Living Under Muslim Laws yang merupakan kumpulan dari beberapa artikel, serta sebuah buku yang dalam edisi Indonesia bertajuk Setara di Hadapan Allah, yang memuat tiga buah artikelnya bersama-sama tulisan Fatima Mernissi. Sedangkan artikel-artikel lainnya tersebar di beberapa jurnal termasuk Ulumul Qur'an. Melihat aktivitas dan karya-karyanya tentang isu keperempuanan, Riffat Hassan dikukuhkan oleh banyak kalangan sebagai pemikir feminis yang telah memberikan'kontribusi terhadap gerakan feminisme, di Pakistan khususnya dan di dunia Islam pada umumnya.

\section{Kerangka Teori dan Konstruksi Metodologis Pemikiran Riffat Hassan}

Dari pemaparan di atas dapat disimpulkan bahwa faktor-faktor yang mendorong pemikiran Riffat Hassan tentang Feminisme cukup beragam dan kompleks. Pada bagian ini penulis akan melihat konstruksi metodologi dan pendekatan yang ia gunakan dalam memahami al-Qur'an sebagai landasan teorinya.

${ }^{13}$ Fatima Mernissi dan Riffat Hassan, op. cit., hal. 44. Lihat juga Riffat Hassan, 1990 "Feminisme dan AlQuг ‘ал, Percakapan dengan Riffat Hassan”, dalam Ulumul Qur 'an, Vol II, hal.87.

"Abdul Mustaqim, op. cit., hal. 96.

is Fatima Mernissi dan Riffat Hassan, op. cit., hal. 47. 
Dengan term perjuangannya yang ia beri nama "jihad fi sabilillah", Riffat memahami desakan kuat untuk 'mengislamkan masyarakat Muslim', khususnya yang menyangkut norma-norma dan nilai-nilai yang berkaitan dengan perempuan. Menurutnya tantangan paling besar yang menghadang dunia Islam adalah tantangan modernitas. Pengemban tradisi Islam seharusnya menyadari, bahwa kenyataan yang berlangsung di zaman teknologi modern memerlukan adopsi pandangan ilmiah atau rasional yang niscaya membawa serta perubahan-perubahan penting dalam berfikir dan bertindak. ${ }^{16}$ Oleh karena itu, dalam rangka membangun kerangka dasar paradigmatik model kepercayaan baru dalam konteks Islam dan isu-isu keperempuanan, Riffat merasa perlu untuk mengembangkan apa yang disebut orang barat sebagai "teologi feminis", dengan tujuan untuk membebaskan bukan hanya perempuan Muslim, tapi juga laki-laki Muslim dari struktur-struktur dan undang-undang yang tidak adil dan tidak memungkinkan terjadinya relasi yang hidup antara laki-laki dan perempuan. ${ }^{17}$ Idenya ini secara tidak langsung dapat diartikan sebagai gagasan untuk merekonstruksi figh perempuan, yang selama ini tampak sangat diskriminatif.

Dalam kerangka tersebut Riffat mencoba melakukan reinterpretasi terhadap al-Qur'an yang selama ini dipandang mengandung bias patriarkhi, sehingga cenderung merugikan perempuan. Menurut Riffat, dalam menafsirkan alQur'an penting dicatat bahwa ayat-ayat yang ada di dalamnya beragam sifatnya. Ada ayat-ayat yang artinya jelas dan gamblang sehingga bisa langsung dijadikan pedoman aturan atau hukum. Tetapi yang lebih banyak adalah ayat-ayat yang simbolik atau pralambang (baca mutasyabihat). Al-Qur'an juga memuat mitologi-mitologi atau cerita-cerita yang penuturannya juga dibungkus dalam pralambang. Dengan demikian, penafsiran atas ayat-ayat seperti ini sangat tergantung dari cara pandang kita, apakah kita memahaminya secara harfiah atau sebagai pralambang. Dua cara yang berbeda itu akan menghasilkan penafsiran yang berbeda pula. ${ }^{18}$

Menurut Riffat, sampai saat ini pada umumnya tradisi Islam secara kaku tetap bersifat patriarkhal. Oleh karena itu, sumber-sumber dasar seperti alQur'an dan Sunnah, dalam kepustakaan-kepustakaan fiqh hanya ditafsirkan oleh laki-laki Muslim yang enggan melakukan tugas-tugas mendefinisikan status ontologis, teologis, sosiologis dan eksatologi perempuan. Mereka hampir tidak menyadari tingkat pelanggaran terhadap perikemanusiaan (juga terhadap Islam dalam pengertian yang ideal) dalam masyarakat yang male domination, yang dengan fasih dan tanpa lelah terus menerus menegaskan bahwa Islam

\footnotetext{
${ }^{16}$ Ibid.

IT Ibid., hal. 49.

${ }^{18}$ Riffat Hassan, op. cil, hal. 86.
} 
telah cukup memberikan kepada perempuan hak yang lebih banyak daripada tradisi-tradisi agama lain. Hampir tidak mengejutkan mayoritas perempuan Muslim menerima keadaan ini secara pasif. ${ }^{19}$ Oleh karena itu, konstruksi metodologi yang dibangun Riffat Hassan mencerminkan perspektif gender yang ingin melihat dan mendudukkan perempuan dalam nuansa kesetaraan, keadilan, dan kebebasan, dengan dilandasi oleh semangat menghormati hak-asasi manusia.

Untuk itu, ia membangun metodologinya dengan menggunakan metode historis kritis kontekstual melalui dua level pendekatan yaitu: 1) pendekatan normatif-idealis, dengan cara melihat bagaimana al-Qur'an secara normatif memandang perempuan; 2) pendekatan historis-empiris, yaitu dengan melihat bagaimana kondisi empiris yang terjadi (dipraktekkan) terhadap perempuan dalam masyarakat. Dengan demikian, yang dilihat apakah terjadi kesesuaian antara yang idealis dan yang empiris, atau yang normatif dan yang historis. Ternyata, menurut Riffat, realitas di Dunia Islam pada umumnya justru menunjukan hal yang sebaliknya. ${ }^{20}$

Adapun langkah operasional dari metode yang ditawarkannya adalah, pertama, memeriksa ketepatan makna dari suatu konsep dalam al-Qur'an dengan menggunakan analisis semantik. Mengenai ketepatan makna ini berkaitan erat dengan pentingnya aspek bahasa, apalagi mengingat bahasa Arab (sebagai bahasa al-Qur'an) memiliki spesifikasi gender (segala hal diklasifikasikan sebagai muzakkar dan muannas). Langkah ini antara lain digunakan Riffat ketika menafsirkan kembali ayat tentang penciptaan pertama.

Jika mengikuti alur pemikiran Amina Wadud Muhsin yang berpendapat bahwa dalam setiap "pembacaan" al-Qur" an terdapat pra-teks (prior text) yang antara lain berupa "matriks kultural", ${ }^{21}$ kajian Riffat menunjukan bahwa matriks kultural yang menekankan posisi inferior perempuan dan menjadi "pra-teks" dalam membaca al-Qur'an (ayat-ayat tentang perempuan), terutama dibentuk oleh tiga asumsi teologis yang akan diuraikan kemudian. Konsekuensi logisnya, dan merupakan langkah kedua, Riffat akan menguji konsistensi filosofis dari penafsiran yang telah ada.

Sedangkan langkah ketiga, Riffat menggunakan prinsip etis yang didasarkan pada prinsip keadilan yang merupakan pencerminan justice of God. ${ }^{22}$ Dalam hal keadilan Tuhan ini, Riffat berpendapat bahwa karena Allah itu Maha adil-Maha pengasih, maka kata-katanya hanya bisa ditafsirkan dalam istilah-

${ }^{19}$ Fatima Mernissi dan Riffat Hassan, op. cit., hal. 46.

${ }^{20}$ Riffat Hassan, op. cit, hal. 87.

2t Istilah pra-teks (prior-sext) digunakan untuk merujuk pada berbagai perspektif, lingkup maupun latar belakang (matriks kultural)- yang sadar atau tidak membentuk bagaimana si pembaca membaca teks. Kenyataannya matriks kuitural ini sangat berpengaruh dalam menciptakan sikap umum kalangan Muslim terhadap perempuan, yang tidak hanya mempengaruhi posisi perempuan dalam komunitas muslim, tapi juga mempengaruhi posisi perempuan dalam al-Qur'an. Lihat Amina Wadud Muhsin, 1992, Qur'an and, Woman, Kuala Lumpur: Fajar Bakti sdn, Bhd., hal. 7.

" Abdul Mustaqim, Op. cil., hal 98. 
istilah yang selaras dengan kualitas-kualitas ilahi tersebut. Pandangan itu tentu saja berarti menerapkan kriteria keadilan kepada al-Qur'an daripada sekedar menerima begitu saja bahwa al-Qur'an pastilah adil. Atau, ia mengambil pandangan tentang keadilan yang dikembangkan dalam sebagian ayat-ayat alQur'an, dan menggunakannya untuk menilai ayat-ayat lain yang tampaknya mengguncangkan pandangan tentang keadilan. ${ }^{23}$

Dengan metodologi yang ditawarkannya ini, Riffat mencoba mengatasi kesenjangan yang sangat dalam antara yang idealis (menurut al-Qur'an) dengan yang empiris realistis, yang dialami kaum perempuan sebagai pihak yang tidak diuntungkan oleh sistem yang berkembang selama ini.

\section{Pokok-Pokok Pikiran Riffat Hassan}

\section{Isu Kesetaraan Laki-laki dan Perempuan}

Sebagaimana telah disebutkan sebelumnya, adanya matriks kultural yang merupakan "pra-teks" dalam pembacaan al-Qur`an, dapat mempengaruhi interpretasi terhadap al-Qur`an tersebut. Dalam hal isu tentang posisi lakilaki dan perempuan yang dianggap tidak setara, dari hasil kajiannya, Riffat menyimpulkan bahwa anggapan tersebut disebabkan adanya tiga asumsi teologis, yang berkembang bukan hanya dalam tradisi Islam, namun juga dalam tradisi Yahudi dan Kristen. Ketiga asumsi ini adalah: (1) bahwa ciptaan Tuhan yang pertama dan utama adalah laki-laki, karena perempuan diyakini telah diciptakan dari tulang rusuk laki-laki, bahkan yang paling bengkok, (2) bahwa perempuan adalah penyebab utama 'kejatuhan' atau pengusiran manusia dari surga, dan (3) bahwa perempuan diciptakan bukan hanya dari laki-laki tapi juga untuk (melayani) laki-laki. ${ }^{24}$

Dari ketiga asumsi teologis tersebut, Riffat Hassan memusatkan perhatian pada persoalan (asumsi) pertama, yaitu isu tentang penciptaan pertama, karena dianggapnya akan memberikan implikasi yang besar terhadap persoalanpersoalan lainnya. Hal ini dapat dilihat dari kutipan berikut ini:

"Saja menganggap hal ini (penciptaan pertama) baik secara filosofis maupun teologis, lebih penting dan mendasar daripada isu-isu lain dalam konteks kesetaraan laki-laki dan perempuan. Sebab jika laki-laki dan perempuan telah diciptakan setara oleh Allah sebagai penentu nilai tertinggi, maka di kemudian hari tidak bisa menjadi tidak setara. Prinsip lain jika laki-laki dan perempuan telah diciptakan tidak setara oleh Allah, maka secara essensial di kemudian hari mereka tidak bisa menjadi setara. "25

3 Ghazala Anwar, 1997, "Wacana Teologi Feminis Muslim”, dalam Zakiyyudin Baidhawy, Wacana Teologi Feminis Perspektif Agama-agama, Geografis, dam Teori-teori, Yogyakarta: Pustaka Pelajar, hal.11-12. Dengan demikian Riffat mengasumsikan bahwa kandungan al-Qur an sebenarnya menupakan satu jalinan pengertian yang saling menguatkan antara satu dengan yang lainnya, dan membentuk suatu sistem nilai yang utuh, sehingga mustahil saling bertentangan. Lihat Abdul Mustaqim, op. cit., hal. 98.

24 Fatima Mernissi dan Rifffat Hassan, op. cit., hal. 54.

$\because$ lbid., hal. 55. 
Secara tegas Riffat Hassan menolak asumsi bahwa perempuan merupakan ciptaan kedua (second order), baik secara kronologis maupun yang lebih penting secara ontologis. Ketika menguji asumsi ini dengan ayat-ayat alQur'an, Riffat menemukan bahwa dalam 30 ayat atau lebih pada berbagai juz dalam al-Qur'an yang menggambarkan penciptaan manusia yang dirujuk dengan istilah-istilah generik (al-insan, an-nas, al bashar), kendati rujukan untuk penciptaan manusia secara seksual oleh Allah dibedakan, tapi tidak ada prioritas ataupun superioritas diberikan baik pada laki-laki maupun perempuan. ${ }^{26}$

Mengenai ayat-ayat yang merujuk pada penciptaan manusia dari satu sumber (nafs wahidah), yaitu QS. An-Nisa (4):1, al-A'raf (7): 189, dan az-Zumar (39): 6 , sejauh ini telah dianggap dapat membuktikan prioritas ontologis dan superioritas laki-laki atas perempuan, karena diyakini bahwa yang dimaksud dengan nafs wahidah adalah seorang laki-laki yang bernama Adam. Penafsiran seperti itu dianggap keliru oleh Riffat Hassan. ${ }^{27}$ Oleh karena itu, kemudian ia berusaha membuktikan dengan melihat makna dari segi semantik linguistik dan mengkritisi sumber-sumber riwayat yang dijadikan sandaran oleh para penafsir atau menjadi "pra-teks" dari pembacan ayat-ayat tersebut.

Riffat Hassan mempertanyakan mengapa dipastikan bahwa nafs wahidah dalam ayat tersebut sebagai Adam yang laki-laki, dan Zawjaha (pasangannya) sebagai Hawwa yang perempuan. Padahal dalam bahasa Arab kata nafs tidak menunjuk kepada laki-laki maupun perempuan, walaupun (bahkan) jenis katanya tergolong mu'annas (feminin). Begitu pula kata zawj tidak secara otomatis berarti istri/ perempuan, tetapi juga netral yaitu pasangan. Dengan mengutip kamus Taj al-Ars yang dipandang otoritatif, Riffat menyatakan bahwa hanya masyarakat Hijaz yang menggunakan istilah zawj untuk merujuk kepada perempuan, sementara di daerah Iain menggunakan zawjah untuk menyatakan pasangan perempuan (istri). Lalu pertanyaannya mengapa alQur'an yang tidak hanya diperuntukan bagi orang Hijaz menggunakan istilah zauj bukan zaujah, seandainya yang dimaksud benar-benar perempuan? ${ }^{28}$

Demikian pula kata "Adam", melalui penelitiannya terhadap teks-teks Injil Genesis 2, Riffat menemukan bahwa kata Adam adalah istilah Hebrew (Ibrani) dari kata adamah yang artinya tanah, yang sebagian besar berfungsi sebagai istilah generik untuk manusia. Menurut Riffat, al-Qur'an tidak pula menyatakan bahwa Adam adalah laki-laki. Adam adalah kata benda yang secara linguistik memang maskulin, namun bukan menyangkut jenis kelamin. Sebagaimana nafs wahidah, Riffat juga tidak memastikan bahwa Adam itu perempuan, tapi

${ }^{26}$ Fatima Mernissi dan Riffat Hassan, op. cit., hal. 60-61.

${ }^{27}$ Jbid., hal. 63.

2 Ibid., hal. 59-60. 
ia menolak dengan tegas jika Adam harus laki-laki. Menurutnya, term Adam sama dengan al-basar, al-insan dan an-nas yang menunjukan kepada manusia secara umum bukan pada jenis kelamin maupun nama diri. ${ }^{29}$

Dengan kata lain, menurut Riffat, Adam dan Hawwa diciptakan secara serentak dan sama substansinya, dan sama pula caranya. Tidak benar jika dikatakan bahwa Adam diciptakan lebih dulu dari tanah, baru kemudian Hawwa diciptakan dari tulang rusuk adam (bahkan yang paling bengkok) sebagaimana kebanyakan pendapat para penafsir. Penafsiran bahwa Hawwa diciptakan dari tulang rusuk Adam ini antara lain disandarkan pada hadis misoginik yang berkembang dan dipandang otoritatif dalam tradisi Islam Sunni, antara lain berbunyi sebagai berikut:

Artinya: "Saling berpesanlah kamu sekalian untuk berbuat baik kepada perempuan , karena mereka dijadikan dari tulang rusuk. Dan sesungguhnya tulang rusuk yang paling bengkok adalah bagian yang paling atas. Jika engkau luruskan tulang yang bengkok itu, engkau akan mematahkannya. Tapi jika engkau biarkan, dia akan tetap bengkok."(H.R. al-bukhari, Muslim dan atTurmuzi).

Riwayat seperti inilah yang menjadi pra-teks penafsiran ayat tentang penciptaan pertama. Berdasarkan penelitian Riffat dan beberapa penafsir lain, ${ }^{30}$ bahwa ide tulang rusuk yang bengkok itu merupakan pengaruh narasi penciptaan perempuan dalam kitab kejadian (2): 18-24, pada Perjanjian Lama milik Yudaisme, yang kemudian menjadi tradisi Kristen dan masuk ke dalam tradisi Islam melalui literatur Hadis. ${ }^{31}$

Sebagai implikasinya, Riffat tentu saja menolak kesahihan hadis tersebut, dan ia melakukan kritik baik terhadap sanad/kritik ekstern (an-naqd al-kharijy) dan intern matan (an-naqd ad-dakhily). Dari segi sanadnya, menurut Riffat hadis ini termasuk kategori $d a$ 'if, karena dalam rangkaian sanadnya terdapat perawi-perawi yang tidak siqah yaitu: Maisarah al-Ashja'i, Haramalah Ibn Yahya, Zaidah, dan Abu Zinad. Riffat mendasarkan penilaiannya kepada pengeritik hadis Samsuddin ad-Dahaby dalam kitab Mizan al-I'tidal fi Naqdi ar-Rijal. Sedangkan dari segi matan, bertentangan dengan al-Qur'an karena mengandung elemen misoginik yang bertentangan dengan konsep al-Qur'an fi ahsan at-taqwim. Riffat juga mengatakan, ia tidak memahami relevansi pernyataan bahwa bagian tulang rusuk yang paling bengkok adalah bagian atas. Lagi pula, nasihat untuk berbuat baik terhadap perempuan, akan

Ibid., hal. 28.

${ }^{30}$ Misalnya Rasyid Ridha, dalam Tafsir al-Mannar IV: 330, menegaskan: "Seandainya tidak tercantum kisah kejadian Adam dan Hawa dalam Kitab Perjanjian Lama, (yakni Kitab Genesis:2) niscaya pendapat yang menyatakan bahwa perempuan diciptakan dari tulang rusuk Adam tidak akan terlintas dalam benak seorang Muslim." Kutipan ini diambil dari M. Quraish Shihab, 1997, Wawasan Al-Qur'an: Tafsir Maudhu'i Atas Pelbagai Persoalan Umat, Bandung: Mizan, hal. 301.

${ }^{31}$ Fatima mernissi dan Riffat Hassan, op. cit., hal. 55-56. 
menimbulkan pengertian bahwa perempuan sebenarnya memang dilahirkan dengan rintangan alamiah dan perasaan dibutuhkan. Kemudian Riffat juga mengatakan bahwa anjuran untuk mengambil manfaat dari perempuan tanpa berusaha menolong perempuan karena kebengkokannya (dalam hal ini rintangan alamiah) mendorong ke arah hedonisme atau oportunisme dan sulit untuk diapresiasi kendatipun perempuan sungguh memiliki "kebengkokan yang tidak bisa diperbaiki". ${ }^{32}$ Oleh karena itu, Riffat menolak secara tegas otentisitas maupun validitas hadits yang diriwayatkan dari Abu Hurairah itu sebagai Sabda Nabi Saw.

Dari hasil kajian kritis dan reinterpretasi terhadap ayat-ayat al-Qur'an dan al-Hadis, Riffat mengambil kesimpulan bahwa laki-laki dan perempuan kedudukannya setara (al musawwah) baik sejak diciptakan maupun sampai kapan pun. Al-Qur'an juga tidak menciptakan hirarki-hirarki yang menempatkan perempuan sebagai sub-ordinat laki-laki. Menurut al-Qur'an laki-laki dan perempuan diciptakan sebagai makhluk-makhluk yang setara yang menginginkan hidup dalam harmoni dan kesalihan bersama. Sebagai indikatornya Riffat menunjuk ayat-ayat: QS. Al-Baqarah (2): 187, Ali-Imran (3): 195, an-Nisa(4): 124, al-Hujurat(39): 134, dan lain-lainnya, yang mengisyaratkan adanya kesetaraan antara laki-laki dan perempuan.

Terhadap ayat-ayat yang selama ini dijadikan justifikasi kelebih-utamaan kedudukan laki-laki daripada perempuan seperti QS. An-Nisa (4): 34, "arrijal qawwam 'ala an-nisa", menurut Riffat kata qawwam secara linguistik berarti "pencari nafkah" (walaupun selama ini sering diartikan sebagai pelindung, pemimpin, penguasa, dan lain-lainnya), atau mereka yang menyediakan sarana pendukung bagi kehidupan. Jadi, ayat tersebut lebih merupakan pernyataan normatif menyangkut konsep Islam tentang pembagian kerja dalam sebuah struktur keluarga dan masyarakat. ${ }^{33}$

\section{Konsep Poligami menurut Riffat Hassan}

Walaupun hanya ada satu ayat dalam al-Qur'an berbicara mengenai poligami, QS an-Nisa (4): 3, akan tetapi ayat tersebut sering dijadikan legalitas mutlak atas pembolehan melakukan poligami tanpa melihat "konteks" dari ayat tersebut. Menurut Riffat, hanyalah tuduhan klasik tidak berdasar apabila dikatakan alQur'an memperlakukan perempuan tidak adil, apalagi jika dikaitkan dengan Nabi Saw yang juga melakukan poligami, bahkan sampai sembilan istri. Menurut Riffat, apabila ditafsirkan secara benar, izin poligami dalam alQur'an maupun dari teladan Nabi SAW, sesungguhnya sangat berkaitan erat dengan masalah penyantunan anak yatim. Jadi, maksud perkawinan itu

32 lbid., hal. 75-76.

${ }^{33}$ Ibid., hal. 91. 
adalah menikahi ibu anak yatim. Penafsiran seperti ini tidak diragukan lagi karena ayat poligami ini turun ketika banyak terjadi perang yang menewaskan para suami sehingga banyak janda dan anak-anak yatim. Oleh karena itu sesungguhnya pesan moral al-Qur'an tentang masalah poligami ini adalah: pertama, penyantunan anak-anak yatim; kedua, ayat ini berbicara tentang keadilan, maka sebenarnya poligami hanya diperbolehkan dalam kondisi sulit seperti itu. ${ }^{34}$ Sampai pada kesimpulan tersebut, Riffat baru berhasil melihat poligami dari sisi historis saja. Berbeda dengan Nasr Hamid Abu Zayd, yang berusaha melihat wacana al-Qurán tentang poligami melampaui makna historis semata, dengan menguak signifikansi masa kininya, bahkan berusaha menguak dimensi "tak terkatakan" (teori implisit), dari pesan tentang poligami tersebut, sehingga ia sampai pada kesimpulan bahwa hukum al-Quràn tentang poligami sebenarnya adalah berupa larangan.

Riffat juga melihat perkawinan Nabi Saw. Bukan karena gaya promiskuitas atau gaya hidup hedonistik. Hal ini terbukti bahwa Nabi sejak menikah pada usia 25 tahun dengan Khadijah, tidak beristri lagi sampai usia 50 tahun. Selama sisa usianya, dari sekian banyak pernikahan yang dilakukannya, hanya 'Aisyah istri beliau yang belum pernah menikah sebelumnya. Itupun lebih karena alasan persahabatan atau yang biasa disebut perkawinan diplomatik. Bahkan, Nabi juga menikahi seorang budak dari Mesir, yang berubah statusnya menjadi perempuan merdeka setelah melahirkan seorang anak laki-laki dari Nabi, walaupun anaknya kemudian meninggal. ${ }^{35}$

\section{Teori Sistem Purdah menurut Riffat Hassan}

Sistem purdah selama ini telah menjadi institusi kaum Muslim selama berabad-abad, sehingga menjadi bagian integral dari masyarakat Muslim. Purdah untuk perempuan seringkali menjadi simbol "islamisasi" suatu negara, dan menempatkan perempuan hanya pada wilayah privat sedangkan laki-laki pada wilayah publik. Apabila perempuan merambah wilayah publik, maka harus menggunakan "purdah", yang berarti keberadaannya seolah-olah tanpa muka, tanpa suara, bahkan tanpa identitas. Menurut Riffat pada akhirnya sistem purdah dijadikan kepanjangan dari prinsip segregasi. ${ }^{36}$

Secara umum al-Qur'an berbicara mengenai prinsip kesahajaan. Qur'an mengatakan bahwa perempuan harus bersahaja, bukan hanya dalam berpakaian, tapi juga dalam berjalan, bertingkah laku, bicara, dan apapun. Namun harus diingat prinsip yang sama dianjurkan pula untuk laki-laki. Adapun indikasi ayat al-Qur'an tentang purdah sebagaimana dalam al-Ahzab (35): 59, yaitu perintah memakai purdah bagi istri-istri Nabi, sangat berkaitan

\footnotetext{
${ }^{34}$ Riffat Hassan., op. cit, hal. 88.

${ }^{33}$ Ibid., hal. 88.

${ }^{35}$ lbid., hal. 89 .
} 
dengan konteks waktu itu, dan bertujuan agar mareka tidak diganggu. Oleh karena itu implikasi logis dari ayat tersebut: pertama, al-Qur'an sama sekali tidak mengatakan bahwa perempuan' tidak boleh keluar rumah atau bekerja di luar rumah. Kedua, apabila mereka terpaksa harus berada di luar rumah, mereka harus berpakaian sedemikian rupa "pantas", sehingga akan dipandang dan diperlakukan secara baik-baik dan tidak diganggu. Purdah yang secara bahasa maknanya memencilkan atau memisahkan, dimaksudkan untuk menghindarkan perempuan dari pandangan dan perbuatan yang menjurus ke arah dijadikan sebagai objek seks. ${ }^{37}$

Jadi pada dasarnya Riffat tidak menolak sistem purdah, karena sebenarnya purdah dianjurkan dalam rangka memberikan keamanan bagi perempuan dari 'fitnah' dan gangguan. Selain itu, pada prinsipnya sistem purdah dapat diartikan sebagai pakaian yang menurut rasa kepantasan setempat menjadikan perempuan dihormati kemanusiaannyá: Dengan demikian, jika menyimpulkan dari pemikiran Riffat, apabila ukurannya 'kepantasan' dan cukup aman untuk tidak menarik perhatian dan dijadikan objek seks, maka jika suatu bentuk pakaian sudah dianggap "pantas" mínurut budaya tertentu, bisa jadi tidak harus memakai purdah.

\section{E. Analisa Kritis terhadap Pemikiran Riffat Hassan}

Sebagai gejala budaya tafsir atau penafsiran al-Qur'an memang bisa dikaji secara ilmiah dan dikritisi. Begitu pula pemikiran atau gagasan-gagasan Riffat Hassan, yang melakukan reinterpretasi terhadap ayat-ayat al-Qur'an tentang penciptaan perempuan, bisa pula (patut) untuk dikaji dan dikritisi. Oleh karena itu pada bagian ini, akan dikemukakan kajian-kajian kritis terhadap pemikiranpemikiran Riffat Hassan, baik yang dikemukakan oleh peneliti lain, maupun hasil analisis penulis sendiri.

Dalam al-Qur'an tidak dijumpai ayat yang secara rinci menceritakan asalusul kejadian perempuan. Ayat yang diyakini sebagai indikasi penciptaan perempuan adalah QS. An-Nisa (4): 1 . Akan tetapi terhadap ayat ini, masih terbuka peluang untuk didiskusikan. Para Mufassir pada umumnya, misalnya dalam kitab kitab tafsir mu'tabar dari kalangan jumhur seperti: Tafsir alQurtuby, Tafsir al-Mizan, Tafsir Ibn Katsir, dan lain-lainnya, semuanya menafsirkan kata nafs wahidah dengan Adam, dan kata zauj dengan Hawwa, istri Adam. ${ }^{38} \mathrm{Hal}$ ini pada umumnya disandarkan pada riwayat hadis yang menerangkan bahwa Hawwa memang diciptakan dari tulang rusuk Adam, sebagaimana telah disebutkan di atas.

${ }^{37}$ Fatima Mernissi dan Riffat Hassan, op. cit., hal. 89.

34 Nassaruddin Umar, 1998, "Perspektif Jender dalam Islam", dalam Pemikiran Islan Jakarta: Paramadina, vol. I, No. 1 hal. 103. 
Pada bagian terdahulu telah dikemukakan bahwa Riffat Hassan menelaah kembali ayat tentang penciptaan pertama, dengan meneliti ketepatan makna dari kata-kata: nafs wahidah, zauj, dan Adam. Riffat menolak jika nafs wahidah sebagai sumber asal manusia, dipastikan sebagai Adam dan berjenis kelamin laki-laki, sedangkan zaujnya sebagai Hawwa yang berjenis kelamin perempuan. Riffat juga mengatakan kata Adam dalam ayat-ayat al-Qur'an lebih menunjukan istilah generik seperti al-insan, al basar, dan an-nas daripada menunjukan nama diri. Sedangkan Yunahar Ilyas melalui tesisnya, dengan melakukan penafsiran ayat dengan ayat lain dari al-Qur'an dalam upaya untuk menemukan jawaban mengenai siapakah yang dimaksud nafs wahidah tersebut, mendapatkan penjelasan dari ayat-ayat lain bahwa manusia pertama diciptakan dari tanah \{ QS, Fathir(35): 11 dan QS. Al-Hijr(15): 26\}. Sementara Qs. Ali-Imran (3): 59 menceritakan penciptaan Isa yang dimisalkan dengan penciptaan Adam, dan disebutkan pula bahwa Adam diciptakan dari tanah. Dari penafsiran ayat demi ayat di atas, Yunahar mengambil kesimpulan bahwa manusia pertama yang diciptakan oleh Allah berasal dari tanah dan merupakan sumber dari seluruh manusia adalah Adam. ${ }^{39}$ Adam adalah nama diri karena dalam QS Ali Imran (3):59, penciptaan Adam dinisbahkan dengan penciptaan Isa, maka dengan demikian Adam maupun Isa merupkan nama diri bukan istilah generik untuk seluruh manusia, yang diambil dari bahasa Ibrani (adamah)yang berarti tanah.

Mengenai kata zauj, Riffat Hassan mempermasalahkan sekiranya Adam laki-laki, maka menurutnya kata yang paling tepat digunakan adalah kata zaujah. Akan tetapi menurut Nasaruddin Umar, alasan Riffat ini lemah. Karena kata zauj dalam ayat lebih menekankan arti pasangan (pair), dengan demikian walaupun menunjukan makna istri tidak mesti menggunakan huruf $t a$ marbutah (menjadi zaujah). Lagipula kata ganti (damir) yang merujuk ke Adam, semuanya menggunakan damir muzakkar ${ }^{40}$. Selain itu, argumen Riffat bahwa kata zauj hanya digunakan di Hijaz, padahal al-Qur'an diperuntukkan bukan hanya bagi orang Hijaz, menurut hemat penulis terlalu mudah dipatahkan. Misalnya apabila ditarik ke cakupan yang lebih luas, akan muncul pula pertanyaan mengapa al-Qur'an diturunkan dengan bahasa Arab, padahal diyakini diturunkan untuk seluruh alam. Petunjuk al-Qur'an yang menyatakan bahwa Qur'anan 'Arabiyyan, menegaskan bahwa al-Qur'an (tidak perlu dipertanyakan lagi) memang diturunkan dalam bahasa Arab. Atau kata bi allisani qaumih, menunjukan bahwa al-Qur'an diturunkan dalam bahasa kaum Nabi Muhammad Saw, yang hidup dan tinggal di wilayah Hijaz. Namun kaum Muslimin di seluruh dunia tetap meyakini dan mengimani al-Qur'an sebagai pedoman hidup.

\footnotetext{
39 Yunahar Ilyas, 1997, Feminisme dalam Kajian Tafsir al-Qur'an Klasik dan Kontemporer, Yogyakarta: Pustaka Pelajar, hal. 108.

“Nasaruddin Umar, op. cit. Catatan kaki No. 18, hal. 102.
} 
Mengenai hadis yang menurut Riffat susupan dari narasi Kitab Kejadian (genesis) dalam Perjanjian Lama, yang dari segi sanadnya dia anggap mengandung empat orang perawi yang $d a$ 'if, ternyata terbukti Riffat kurang teliti mencermati nama-nama perawi tersebut. Padahal dalam diskursus takhrij al-hadis diperlukan ketelitian dalam mencermati nama perawi agar tidak keliru dengan perawi lain yang namanya hampir sama. Hal ini dapat dilakukan dengan melihat nama keluarganya, nama murid ataupun nama gurunya. Dalam ad-Dahaby ternyata keempat perawi hadis tersebut tidak di-da' $i f k a n$. Bahkan Abu Zinad perawi hadis al-Bukhari dan Muslim, dinilai dengan siqah sahur (terkenal terpercaya), dan Haramalah dinilai sebagai asaddu al-' a'immah assiqah (salah seorang imam terpercaya). ${ }^{41}$

Penolakannya tehadap matan hadis yang dianggapnya mengandung elemen misoginis, menurut Abdul Mustaqim disebabkan karena Riffat terlalu tekstualis skripturalis ketika memahami hadis tersebut. ${ }^{42}$ Penilaian Riffat bahwa hadis tentang tulang rusuk itu bertentangan dengan konsep al-Qur'an $f i$ ahsan attaqwim , sebenarnya tidak terbukti. Karena konsep fi ahsan at-taqwim berbicara mengenai wujud atau bentuk tubuh manusia yang selaras setelah diciptakan, bukan mengenai proses penciptaan itu sendiri. ${ }^{43}$ Jika hadis itu dipahami secara metafor (mazaji), hadis itu dapat dipahami sebagi peringatan terhadap lakilaki agar dalam menghadapi perempuan dapat bersikap bijaksana, karena ada karakter dan kecenderungan perempuan yang berbeda dengan laki-laki. ${ }^{44}$

Asumsi dasar Riffat Hassan yang menyatakan bahwa sekali laki-laki dan perempuan diciptakan tidak setara maka akan selamanya tidak setara, ternyata menjadi "pra teks" bagi Riffat ketika membaca (menafsirkan) kembali ayatayat al-Qur" an tentang perempuan. Pada akhirnya, argumen-argumen Riffat selalu diarahkan untuk membuktikan kesetaraan pada saat penciptaan, yang dalam beberapa hal tampak dipaksakan dan mengandung kelemahan. Padahal menurut hemat penulis, perbedaan saat penciptaan secara kronologis, maupun perbedaan lainnya (ex: biologis) tidak akan mempengaruhi kedudukan lakilaki dan perempuan di mata Allah, sebagaimana dinyatakan dengan tegas dalam al-Qur`an bahwa hanya ketaqwaanlah yang dipandang Tuhan.

\section{F. Penutup}

Dari pemaparan di atas terlihat bahwa kondisi sosio-kultural-religius bahkan politik dalam masyarakat yang membesarkannya telah membentuk Riffat menjadi seorang teolog feminis yang bercita-cita membebaskan kaum perempuan dari keterkungkungan tradisi patriarkhi, yang seolah-olah mendapat

\footnotetext{
4l Yunahar Ilyas, op. cit., hal, 114-116.

t2 Abdul Mustaqim, op. cit., hal. 107.

${ }^{43}$ Yunahar Ilyas, op. cit., hal.120.

"Quraish Shihab, op.cit., hal. 300.
} 
legitimasi dari (penafsiran) doktrin-doktrin teologis yang sarat dengan gender bias. Oleh karena itu, Riffat mencoba melakukan re-interpretasi terhadap ayat-ayat al-Qur'an dengan menelaah dan mengkritisi prior text (pra-teks) yang melatar belakangi penafsiran para ulama terdahulu, yang selama ini telah membentuk opini umat.

Tanpa mengurangi penghargaan terhadap semangatnya dalam mengusung ide kesetaraan dan keadilan yang merupakan pesan dasar moral al-Qur'an, pemikiran-pemikiran Riffat Hassan -sebagai sebuah human constructionternyata tidak terlepas dari kelemahan-kelemahan dan kekurangan. Namun demikian, sebagai suatu hasil ijtihad, gagasan-gagasan Riffat Hasan yang merupakan suatu usaha "membaca' al-Qur'an dengan optik yang berbeda, yaitu optik teolog feminis perempuan, patut diapresiasi walaupun dalam beberapa hal gagasannya tampak sama dengan pemikir lain (tidak baru). Namun gagasan-gagasan Riffat ini sangat berpengaruh dalam upaya rekonstruksi figh perempuan, yang banyak dibicarakan akhir-akhir ini.

Kesimpulan umum yang dapat ditarik dari pemikiran-pemikiran Riffat Hassan tentang feminisme, adalah bahwa al-Qur'an sangat apresiatif dan tidak diskriminatif terhadap perempuan. Oleh karena itu, penafsiran-penafsiran aIQur'an yang didasari oleh asumsi-asumsi teologis yang keliru, perlu didekonstruksi agar bisa mendudukan laki-laki dan perempuan dalam kesetaraan, keadilan dan kebebasan, yang didasari oleh semangat hak asasi manusia yang merupakan pesan abadi al-Qur'an sebagai satu-satunya sumber nilai tertinggi.

\section{DAFTAR PUSTAKA}

Bashin, Kamla dan Nighat said Khan, 1995, Persoalan Pokok Mengenai Feminisme dan Relevansinya, Jakarta: Gramedia Pustaka Utama.

-----, 1990, “Feminisme dan al-Qur`an”, dalam Ulumul Qur`an, Vol. II, Jakarta.

Hassan, Riffat, 1993, "Mempersoalkan Istilah Fundamentalisme Islam, dalam Ulumul Qur'an, No. 3. Vol. II, Jakarta.

Ilyas, Yunahar, 1997, Feminisme dalam kajian al-Qur'an Klasik dan Kontemporer, Yogyakarta: Pustaka Pelajar.

Jalal, Ayesha, 1991," The Convenience of Subsevience Women and The State of Pakistan", dalam Deniz Kandiyoti (ed.), Women, Islam, and the State, London: Mc. Milian Press, Ltd. 
Mernissi, Fatima dan Riffat Hassan, 2000, Setara di Hadapan Allah, Yogyakarta: LSPPA.

Mernissi, Fatima, 1997, Menengok Kontroversi Peran Wanita dalam Politik, Surabaya: Dunia Ilmu.

Muhsin, Amina Wadud, 1992, Qur'an and Women, Kuala Lumpur: Fajar Bakti Sdn.Bhd.

----, 2001, “ Al-Qur'an dan Perempuan', dalam Charles Kurzman (ed), Wacana Liberal, Pemikiran Islam Kontemporer tentang Isu-isu global, Jakarta: Paramadina.

Mustaqim, AbduI, 1999, “Feminisme dalam Pemikiran Riffat Hassan”, $A l$ Jami'ah, No. 64/ XII, Yogyakarta: IAIN Sunan Kalijaga.

Siddiqi, Muhammad Saeed, 1991, The Modest Status of Women in Islam, Lahore: Kazi Publications.

Sutanto, Trisno S., 1999, “ Tulang Rusuk Adam, Membaca Kembali Kitab Suci dengan Optik Perempuan," dalam Tashwirul Afkar, Jakarta: Lakspedam NU.

Shihab, Quraish, 1997, Membumikan al-Qur'an, Bandung: Mizan.

----, 1997, Wawasan al-Qur'an: Tafșir Maudhu'i atas Pelbagai Persoalan Umat, Bandung: Mizan. 